\title{
CDK8 wt Allele
}

National Cancer Institute

\section{Source}

National Cancer Institute. CDK8 wt Allele. NCI Thesaurus. Code C95298.

Human CDK8 wild-type allele is located in the vicinity of $13 q 12$ and is approximately 151 $\mathrm{kb}$ in length. This allele, which encodes cyclin-dependent kinase 8 protein, is involved in protein phosphorylation and transcriptional regulation. Aberrant expression of the gene may be associated with colon cancer and malignant melanoma. 